\title{
PROBLEM BASED LEARNING DENGAN STRATEGI PEMBELAJARAN AKTIF DI SMAN 3 PALANGKARAYA
}

\author{
(Problem Based Learning By Active Learning Strategies At SMAN - 3 Palangkaraya) \\ ENDANG SRI SUYATI
}

\author{
Program Studi Pendidikan Ekonomi \\ Universitas Muhammadiyah Palangkaraya \\ JI. RTA Milono Km.1,5 Palangka Raya, Kalimantan Tengah 73111
}

e-mail :endang.sriuyati@yahoo.com

\begin{abstract}
This study aims to: (1) To determine the increased activity of learners during the learning process Economic using Active Learning Strategies Type of Problem Based Learning (Problem Based Learning / PBL) Class X7 SMAN 3 Palangkaraya in academic year 2015/2016. (2) To determine the learning outcome of Economics after using the Active Learning Strategies Type of Problem Based Learning (Problem Based Learning/PBL) Class X7 SMAN 3 Palangkaraya Academic Year 2015/2016.

Subjects in this study were all students of class X7 SMAN3 Palangkaraya totaling 37 learners. The method used is using Action Research (PTK). Data collection techniques are observation, documentation, and testing. While the analysis of the data using the percentage of classical completeness.

From the results showed that: (1) Activities of learners are more active during the learning process Economic using Active Learning Strategies Type of Problem Based Learning (Problem Based Learning / PBL) Class X7 SMAN 3 Palangkaraya Academic Year 2015/2016, which is indicated by the acquisition observation score above 3, (2) There is an increasing use of learning outcomes Economic Active learning Strategies type of problem Based learning (problem Based learning / PBL) Class X7 SMAN 3 Palangkaraya in academic year 2015/2016. It is seen from the data is the study of students, the first cycle mastery learning outcomes of students that are klasikalnya is $64.28 \%$ and the second cycle increased to $91.89 \%$. As for the minimum standards prescribed completeness school for Economics lesson is 75.
\end{abstract}

Keywords: Problem Based Learning, Active Learning Strategies

\section{ABSTRAK}

Penelitian ini bertujuan untuk: 1) mengetahui peningkatan aktivitas belajar peserta didik saat proses pembelajaran Ekonomi menggunakan Strategi Pembelajaran Aktif Tipe Pembelajaran Berbasis Masalah (Problem Based Learning/PBL) Kelas X7 SMAN 3 Palangkaraya Tahun Pelajaran 2015/2016 2) mengetahui peningkatan hasil belajar Ekonomi setelah mengunakan Strategi Pembelajaran Aktif Tipe Pembelajaran Berbasis Masalah (Problem Based Learning/PBL) Kelas X7 SMAN 3 Palangkaraya Tahun Pelajaran 2015/2016

Subjek dalam penelitian ini adalah seluruh siswa kelas X7 SMAN3 Palangkaraya yang berjumlah 37 orang peserta didik. Metode yang digunakan adalah menggunakan Penelitian Tindakan Kelas (PTK). Teknik pengumpulan data yang digunakan adalah observasi, dokumentasi, dan tes. Sedangkan analisis data menggunakan persentase ketuntasan klasikal.

Dari hasil penelitian menunjukan bahwa: (1) Aktifitas belajar peserta didik lebih aktif pada saat proses pembelajaran Ekonomi menggunakan Strategi Pembelajaran Aktif Tipe Pembelajaran Berbasis Masalah (Problem Based Learning/PBL) Kelas X7 SMAN 3 Palangkaraya Tahun Pelajaran 2015/2016, yang ditunjukkan dengan perolehan skor pengamatan diatas 3, (2) Ada peningkatan hasil belajar Ekonomi menggunakan Strategi Pembelajaran Aktif Tipe Pembelajaran Berbasis Masalah (Problem Based Learning/PBL) Kelas X7 SMAN 3 Palangkaraya Tahun Pelajaran 2015/2016. Hal ini telihat dari data hasil belajar peserta didik, pada siklus I ketuntasan hasil belajar peserta didik yaitu secara klasikalnya yaitu 64,28\% dan pada siklus II meningkat menjadi 91,89\%. Adapun standar ketuntasan minimum yang ditentukan sekolah untuk pelajaran Ekonomi yaitu 75.

Kata Kunci: Problem Based Learning, Strategi Pembelajaran Aktif 


\section{PENDAHULUAN}

Peran guru dalam kegiatan pembelajaran sangat menentukan dalam mensukseskan program pendidikan, serta menunjang tercapainya keberhasilan belajar peserta didik. Adapun kegiatan pembelajaran yang efektif dan efisien akan tercapai dan tercipta apabila guru mampu memilih dan mau mengembangkan serta menggunakan metode-metode pembelajaran yang tepat untuk menyampaikan materi pembelajaran kepada peserta didik. Oleh sebab itu peserta didik diharapkan dapat berpartisipasi dan berperan aktif dalam kegiatan pembelajaran agar dalam kegiatan belajar mengajar dapat mencapai tujuan hasil belajar yang diinginkan.

Tujuan dari PBL untuk menantang peserta didik mengajukan permasalahan dan juga menyelesaikan masalah yang lebih rumit dari sebelumnya, dapat meningkatkan keaktifan peserta didik dalam mengemukakan pendapatnya, menggalang kerjasama dan kekompakan peserta didik dalam kelompok, mengembangkan kepemimpinan peserta didik serta mengembangkan kemampuan pola analisis dan dapat membantu peserta didik mengembangkan proses nalarnya. Pengajaran berbasis masalah digunakan untuk merangsang berpikir tingkat tinggi dalam situasi berorientasi masalah, termasuk belajar bagaiman belajar. Pengajaran berbasis masalah tidak dapat dilaksanakan jika guru tidak mengembangkan lingkungan kelas yang memungkinkan terjadinya pertukaran ide secara terbuka.Intinya, peserta didik dihadapkan pada situasi masalah yang otentik dan bermakna yang dapat menantang peserta didik untuk memecahkannya.
Berdasarkan hasil observasi yang dilakukan peneliti pada peserta didik kelas X-7 SMA Negeri 3 Palangka raya, fenomena yang dapat dijumpai di sekolah menunjukkan bahwa pelaksanaan kegiatan pembelajaran masih ditemukan kurangnya partisipasi dan keaktifan peserta didik dalam kelas ketika guru menyampaikan pembelajaran. Sehingga ini menyebabkan rendahnya perolehan hasil belajar Ekonomi peserta didik. Hal ini terlihat dari hasil belajar Ekonomi pada peserta didik kelas X-7 SMA Negeri 3 Palangka raya yang masih belum mencapai nilai standar. Sedangkan nilai Kriteria Ketuntasan Minimum (KKM) 75. Jumlah dari peserta didik kelas X-7 SMA Negeri 3 Palangka raya 37 orang peserta didik, 20 orang peserta didik tidak memenuhi ketuntasan belajar dengan nilai 75 kebawah, hanya 17 orang peserta didik yang memenuhi ketuntasan belajar dengan nilai 75 keatas.

Oleh karena itu, guru harus mampu memilih atau menggunakan metode pembelajaran serta mencari cara lain untuk menyampaikan materi pelajaran agar mempermudah peserta didik untuk mencapai tujuan pembelajaran dan menghindari terjadinya kejenuhan yang dialami peserta didik dalam menerima pelajaran khususnya mata pelajaran Ekonomi. Maka salah satu upaya yang harus dilakukan guru untuk meningkatkan hasil belajar Ekonomi menggunakan metode pembelajaran.

Berdasarkan hal di atas, untuk mengatasi masalah hasil belajar Ekonomi pada peserta didik kelas X-7 SMA Negeri 3 Palangka raya adalah dengan menggunakan Strategi pembelajaran Aktif dengan Tipe Pembelajaran Berbasis Masalah (Problem Based learning/PBL). Adapun masalah 
dalam penelitian ini adalah: 1) bagaimanakah aktivitas belajar peserta didik pada saat proses pembelajaran Ekonomi menggunakan Strategi Pembelajaran Aktif Tipe Pembelajaran Berbasis Masalah (Problem Based Learning/PBL) kelas X-7 SMA 3 Palangka raya tahun pelajaran 2015/2016? dan 2) apakah ada peningkatan hasil belajar Ekonomi setelah menggunakan Strategi Pembelajaran Aktif Tipe Pembelajaran Berbasis Masalah (Problem Based Learning/PBL) Kelas X7 SMA 3 Palangka raya Tahun Pelajaran 2015/2016?

Belajar pada hakikatnya merupakan suatu aktivitas untuk memperoleh perubahan tingkah laku pada dirinya baik potensial maupun aktual, yaitu perubahan secara kognitif, afektif, maupun psikomotorik. Beberapa ahli pendidikan memberikan penafsiran yang berbeda-beda untuk mendefinisikan pengertian belajar. Namun perbedaan itu hanya sebatas variasi dalam mengungkapkan gagasan serta hasil dari pengamatan saja. Oleh sebab itu, akan dikemukakan beberapa pengertian belajar menurut para ahli pendidikan.

Menurut Slameto (Dalam Sugiyono, 2010:2) "belajar adalah suatu proses usaha yang dilakukan seseorang untuk memperoleh suatu perubahan tingkah laku yang baru secara keseluruhan, sebagai hasil pengalamannya sendiri dalam interaksi dengan lingkungan". Sementara itu, menurut Abdillah (Dalam Annurrahman, 2008:27) "Belajar adalah suatu usaha sadar yang dilakukan oleh individu dalam perubahan tingkah laku baik melalui latihan dan pengalaman yang menyangkut aspek-aspek kognitif, efektif dan psikomotorik untuk memperoleh tujuan tertentu".
Berdasarkan beberapa pendapat di atas dapat disimpulkan bahwa belajar merupakan proses perubahan tingkah laku yang terjadi pada manusia, yang awalnya belum tahu menjadi tahu dan yang awalnya tidak bisa menjadi bisa.

Dengan memahami prinsip - prinsip belajar kita akan lebih mudah dan lebih cepat berhasil dalam belajar. Menurut Suryabrata (Sugiyono, 2010:8), adapun salah satu prinsip belajar tersebut adalah "Belajar harus pada tujuan yang jelas". Dengan menetapkan suatu tujuan yang jelas, setiap peserta didik akan dapat menentukan arah dan juga tahap-tahap belajar yang harus dilalui dalam mencapai tujuan belajar tersebut. Selain itu, dengan adanya tujuan belajar yang jelas, keberhasilan belajar peserta didik dapat dilihat dan sejauh mana ia mampu mencapai tujuan belajarnya itu.

Sedangkan menurut Dimyati dan Mudjiono (Dalam Rinati, 2013:7) "Hasil belajar merupakan hasil dari suatu interaksi tindak belajar dan tindak mengajar. Dari sisi guru, tindak mengajar diakhiri dengan proses evaluasi belajar. Dari sisi peserta didik, hasil belajar merupakan berakhirnya pelajaran dari puncak proses belajar".

Berdasarkan beberapa pendapat di atas maka dapat disimpulkan bahwa hasil belajar adalah kemampuan yang diperoleh setelah melalui kegiatan belajar. Karena belajar itu sendiri merupakan suatu proses dari seseorang yang berusaha untuk memperoleh suatu bentuk perubahan perilaku yang relatif menetap.

Menurut teori Gastalt (Sujiyono, 2010: 20), belajar merupakan suatu proses perkembangan. Artinya bahwa secara kodrati jiwa raga anak mengalami perkembangan. Perkembangan sendiri memerlukan sesuatu baik 
yang berasal dari peserta didik sendiri maupun pengaruh dari lingkungannya. Berdasarkan teori ini hasil belajar peserta didik dipengaruhi oleh dua hal, peserta didik itu sendiri dan lingkungannya. Pertama, peserta didik; dalam arti kemampuan berpikir atau tingkah laku intelektual, motivasi, minat, dan persiapan peserta didik, baik jasmani maupun rohani. Kedua, lingkungan; yaitu sarana dan prasarana, kompetensi guru, kreatifitas guru, sumber-sumber belajar, metode serta dukungan lingkungan, keluarga, dan lingkungan.

Menurut Wasliman (Susanto, 2013:12), "Hasil belajar yang dicapai peserta didik merupakan hasil interaksi antara berbagai faktor yang mempengaruhi, baik faktor internal maupun eksternal". Menurut Slameto (Sanjaya, 2011:9) faktor-faktor yang mempengaruhi hasil belajar adalah; 1) Faktor Internal, yaitu Jasmani meliputi kesehatan dan cacat tubuh. Psikologi meliputi intelegensi, perhatian minat, bakat, dan kematangan, 2) Faktor Eksternal, yaitu keluarga yang meliputi cara orang tua mendidik, susanana rumah tangga, perhatian orang tua, latar belakang keluarga, relasi antara anggota keluarga, keadaaan anggota keluarga. Sekolah, meliputi metode mengajar, relasi guru dengan peserta didik, kurikulum, relasi peserta didik dengan teman sebaya, disiplin sekolah, alat pengajaran, waktu sekolah, tugas rumah, standar pelajaran diatas ukuran, keadaan gedung, dan metode belajar. Masyarakat yang meliputi kegiatan peserta didik dalam masyarakat, media masa, teman bergaul, dan bentuk kehidupan masyarakat.

Menurut Clark (Sari'at, 2013: 10) "Hasil belajar peserta didik disekolah $70 \%$ dipengaruhi oleh kemampuan peserta didik dan 30\% dipengaruhi oleh lingkungan".

Berdasarkan pendapat di atas dapat disimpulkan bahwa faktor-faktor yang mempengaruh hasil belajar ada dua yaitu faktor internal dan faktor eksternal yang sangat erat hubungannya dengan peserta didik.

Menurut Soemarsno (Sanjaya 2011: 3) sebagai berikut: Ekonomi merupakan ilmu tentang perilaku dan tindakan manusia untuk memenuhi kebutuhan hidupnya yang banyak, bervariasi, dan berkembang dengan sumber daya yang ada melalui pilihan-pilihan kegiatan produksi, konsumsi, atau distribusi. Menurut Soemarsono (Sanjaya 2011: 8-10) menjelaskan fungsi dan tujuan ekonomi sebagai berikut: Fungsi mata pelajaran ekonomi adalah mengembangkan kemampuan siswa untuk berekonomi, dengan cara mengenal berbagai kenyataan dan peristiwa ekonomi, memahami konsep dan teori serta berlatih dalam memecahkan masalah ekonomi yang terjadi di lingkungan masyarakat.

Tujuan mata pelajaran ekonomi di Sekolah Menengah Atas adalah: a) membekali peserta didik sejumlah konsep ekonomi untuk mengetahui dan mengerti peristiwa dan masalah ekonomi dalam kehidupan sehari-hari, terutama yang terjadi di lingkungan setingkat individu, rumah tangga, masyarakat dan negara, b) membekali peserta didik sejumlah konsep ekonomi yang diperlukan untuk mendalami ilmu ekonomi pada jenjang selanjutnya, c) membekali peserta didik nilai-nilai serta etika ekonomi dan memiliki Jiwa wirausaha, dan c) meningkatkan kemampuan berkompetensi dan bekerjasama dalam masyarakat yang majemuk, baik dalam skala nasional maupun skala 
internasional.

\section{Menurut Soemarsono (dalam Sanjaya} 2011:20) menjelaskan ruang lingkup pembelajaran ekonomi sebagai berikut: Ruang lingkup mata pelajaran ekonomi di SMA dimulai dan masalah- masalah ekonomi yang terjadi di lingkungan kehidupannya yang terdekat hingga pada lingkungan yang terjauh. Adapun ruang lingkup pelajaran ekonomi di SMA adalah perilaku ekonomi dan kesejahteraan yang secara rinci mencakup aspek-aspek sebagai berikut: 1) berekonomi, 2) ketergantungan, 3) spesialisasi dan pembagian kerja, 4) perkoperasian, dan 5) kewirusahaan.

Berdasarkan pendapat diatas mengenai ekonomi, peneliti membatasi pengertian ekonomi dalam hal ini sebagai suatu mata pelajaran yang harus dipelajari dan dikuasai oleh peserta didik sekolah menengah atas atau pun sekolah menengah kejuruan yang berhubungan dengan materi sesuai yang tercantum dalam kurikulum yang digunakan masing-masing sekolah.

Strategi Pembelajaran Aktif adalah segala bentuk pembelajaran yang memungkinkan peserta didik berperan secara aktif dalam proses pembelajaran,baik dalam bentuk interaksi antar peserta didik ataupun peserta didik dengan guru dalam proses pembelajaran (Warsono \& Hariyanto, 2012: 3). Pembelajaran aktif mengkondisikan agar peserta didik selalu melakukan pengalaman belajar yang bermaakna dan senantiasa berpikir tentang apa yang dapat dilakukannya. Menurut Bonwell dan Eison (Warsono \& Hariyanto, 2012:14) seluruh bentuk pengajaran yang berfokus kepada peserta didik sebagai penanggung jawab pembelajaran adalah pembelajaran aktif. Jadi, menurut kedua ahli tersebut pembelajaran aktif mengacu kepada pembelajaran berbasis siswa (Studen-Centered Learning). Dalam hubungan ini Centre for Research on Learning and Teaching Universary of Michigan, memberikan defenisi yang lebih ketat lagi tentang pembelajaran aktif. Menurut Lembaga tersebut, pembelajaran aktif adalah suatu proses yang memberikan kesempatan kepada para siswa terlibat dalam tugas-tugas pemikiran.

Dalam pembahasan terlihat bahwa pembelajaran aktif lebih menekankan pada pendekatan pembelajaran, dengan esensi mengaktifkan peserta didik dalam pembelajaran. Jumlah peserta didik dalam pembelajaran aktif bersifat bebas, boleh perorangan atau kelompok belajar, yang terpenting peserta didik harus aktif. Terkait pembelajaran aktif, ada satu hal yang patut dipahami berupa konsep yang dikembangkan oleh L. Dee Fink. Menurut Fink (Warsono\& Hariyanto, 2012:25) pembelajaran aktif terdiri dari dua komponen utama, yakni Komponen pengalaman (Experience) dan komponen dialog. Lebih lanjut komponen pengalaman terdiri dari pengalaman melakukan (Doing) dan pengalaman mengamati (Observing). Sedangkan komponen dialog terdiri dari dialog dengan diri sendiri (Dialogue with self), dan dialog dengan orang lain (Dialogue with Others). Dalam komponen melakukan (Doing), peserta didik benar-benar melakukan sesuatu secara nyata oleh dirinya sendiri. Dan dalam komponen mengamati (Observing), peserta didik dapat melihat dan mendengarkan.

Menurut Bonwell (Warsono\& Hariyanto, 2012:27), pembelajaran aktif memiliki beberapa karakteristik sebagai berikut: 1) menekankan 
pada proses pembelajaran, 2) peserta didik di rangsang aktif dalam proses pembelajaran, 3) penekanan pada eksplorasi nilai dan sikap tanggapan, 4) peserta didik lebih dituntut berpikir kritis, menganalisis dan mengevaluasi dari proses pembelajaran, dan 5) adanya umpan balik dari proses pembelajaran yang terjadi. Terkait hal tersebut, Mc Keachie (dalam Warsono\& Hariyanto, 2012:8) mengemukakan dimensi implementasi pembelajaran siswa aktif yang meliputi: a) partisipasi siswa dalam menentukan tujuan kegiatan pembelajaran, b) penekanan kepada aspek afektif dalam pembelajaran, c) partisipasi siswa dalam melaksanakan kegiatan belajar- mengajar, terutama yang berbentuk interaksi antar murid, d) penerimaan terhadap aspirasi siswa, e) kesempatan yang diberikan kepada siswa untuk mengambil keputusan atas suatu pembelajaran, dan f) keeratan hubungan kelas. Dalam hal ini Arends mengutip hasil penelitian para ahli antara lain Vanderbilt, Krajcik \& Czerniak Slavin (Amir Taufiq. M, 2009: 12) menyimpulkan ada lima gambaran yang umum menjadi identifikasi pembelajaran berbasis masalah, yaitu: 1) dikembangkan dari pentanyaan atau masalh. PBL mengorgaisasikan pengajaran pada sejumlah pertanyaam atau masalah yang penting, yang baik secara sosial maupun personal bermakna bagi peserta didik. Pendekatan ini mengaitkan pembelajaran dengan situasi kehidupan nyata, 2) diterapkan untuk memusat subjek tertentu agar dapat diinvestigasi, 3) penyelidikan otentik. Hal ini selalu dikaitkan dengan masalah yang timbul di kehidupan nyata, yang langsung dapat diamati. Dan dari masalah yang timbul juga harus dicarikan penyelesaian secara nyata. Para peserta didik harus menganalisis dan mendefenisikan masalahnya, mengembangkan, mengumpulkan dan menganalisis informasi dan menarik simpulan yang tentu saja bergantung pada sifat-sifat masalah yang dikaji, 4) menghasilkan umpan balik yaitu berupa kesimpulan dan hasil pelaporan, dan 5) adanya kolaborasi. Implementasi PBI ditadai oleh adanya kerja sama antar peserta didik satu sama lain, biasanya dalam pasangan peserta didik atau kelompok kecil. Bekerja sama akan memberikan motivasi untuk terlibat berkelanjutan dalam tugastugas komplek, meningkatkan kesempatan untuk saling bertukar pikiran dan mengembangkan inkuiri, serta melakukan dialog untuk mengembangkan kecakapan sosial.

$\mathrm{PBI}$ atau PBL baru dapat berkembang jika terbangun suaatu situasi kelas yang efektif. Combs (dalam Amir Taufiq. M, 2009:21) seperti yang di ungkap oleh Nort Central Educational Library (2006) menyatakan bahwa minimal ada tiga karakteristik yang harus dipenuhi agar terbangun situasi kelas yang efektif dalam PBL, yaitu sebagai berikut: 1) para peserta didik harus merasa aman dan merasa diterima. Dimana situasi kelas harus mampu menyediakan kesempatan bagi mereka untuk terlibat, saling berinteraksi dan sosialisasi, 2) para peserta didik harus saling diberi kesempatan untuk mengkonfrontasikan informasi baru dengan pengalamannya selama proses pencarian makna, 3) makna baru tersebut harus diperoleh melalui proses penemuan secara personal. Berkaitan dengan filosofi seperti diatas berkembanglah apa yang disebut Problem Based Learning. Problem Based Learning (Pembelajaran 
Berbasis Masalah) atau sering juga disebut PBI (Problem Based Instruction) merupakan suatu tipe pengelolaan kelas yang diperlukan untuk mendukung pendekatan konstruktivisme dalam pengajaran dan belajar. Dalam sumber yang sama, Savoie dan Hughes (Amir Taufiq. M, 2009: 24) mengungkap perlunya suatu proses yang dapat digunakan untuk mendesain pengalaman pembelajaran berbasis masalah bagi peserta didik. Kegiatan-kegiatan yang diperlukan dalam menunjang proses tersebut, yaitu sebagai berikut: a) Identifikasikan suatu masalah yang cocok bagi para peserta didik, b) Kaitkan masalah tersebut dengan konteks dunia peserta didik sehingga mereka dapat menghadirkan suatu kesempatan otentik, c) o rganisasikan pokok bahasan kepada suatu masalah. Berilah para peserta didik tanggung jawab untuk dapat mendefenisikan sendiri pengalaman belajar mereka serta membuat perencanaan dalam penyelesaian masalah, d) berikan dukungan kepada semua peserta didik untuk mendemonstrasikan hasil-hasil pembelajaran mereka misalnya dalam bentuk suatu karya atau kinerja tertentu.

PBM utamanya dilaksanakan untuk membantu peserta didik mengembangkan kemampuan berpikir, pemecahan masalah, keterampilan, intelektual, belajar berbagai peran orang dewasa dengan melibatkan mereka dalam pengalaman nyata atau simulasi (dalam Warsono \& Hariyanto, 2012:12). Sebagaimana pendekatan pembelajaran yang lain, problem based learning juga mempunyai tahapan atau sintaks dalam pelaksanaannya. Sintaks untuk problem based learning menurut Arends (Amir Taufiq. M, 2009:28) terdiri dari lima fase. Dapat dilihat pada tabel 1.

Pada intinya problem based learning merupakan suatu pembelajaran yang menggunakan masalah dunia nyata disajikan di awal pembelajaran. Kemudian masalah tersebut diselidiki untuk diketahui solusi dari pemecahan masalah tersebut oleh siswa. Problem based learning tidak dirancang untuk membantu guru untuk menyampaikan informasi dalam jumlah yang besar kepada siswa. Problem based learning benar-benar dirancang untuk membantu siswa dalam mengembangkan keterampilan berfikir, keterampilan menyelesaikan masalah, dan keterampilan intelektualnya untuk mempelajari peran orang dewasa melalui berbagai situasi riil atau situasi yang disimulasikan sehingga siswa akan menjadi pelajar yang mandiri dan otonom.

\section{METODOLOGI PENELITIAN}

Penelitian ini dilaksanakan pada bulan Februari sampai dengan bulan Juni 2016. Penelitian ini dilaksanakan di SMA Negeri 3 Palangka raya yang terletak di Jalan George Obos Kota Palangka Raya pada kelas X-7. Pemilihan tempat penelitian ini didasarkan pada keterkaitan sekolah dengan judul penelitian yang diajukan oleh peneliti dan fenomena yang terlihat di sekolah terkait dengan pembelajaran Ekonomi. Metode penelitian yang digunakan dalam penelitian ini adalah Penelitian Tindakan Kelas (Classroom Action Research). Menurut Sugiyono (2009:6) menyatakan bahwa "Secara umum metode penelitian diartikan sebagai cara ilmiah untuk mendapatkan data yang valid dengan tujuan dapat ditemukan, dikembangkan, dan dibuktikan, sesuai pengetahuan tertentu sehingga 
pada gilirannya dapat digunakan untuk memahami, memecahkan, dan mengantisipasi masalah dalam bidang pendidikan". Sedangkan menurut Kunandar (2010:45) menyatakan bahwa "PTK adalah penelitian tindakan yang dilakukan dengan tujuan memperbaiki mutu praktik pembelajaran di kelas". Sedangkan menurut ( dalam Mulyasa, 2011:10) menyatakan bahwa "PTK dapat diartikan sebagai penelitian tindakan (action research) yang dilakukan dengan tujuan untuk memperbaiki kualitas proses dan hasil belajar sekelompok peserta didik". Menurut model Kemis \& Mc Taggart (dalam Harawati, 2012:13), pelaksanaan penelitian tindakan mencapai empat langkah, yaitu: 1). perencanaan tindakan (planning), 2). pemberian tindakan (acting), 3). observasi (observing), dan 4). refleksi (reflecting).

Pada refleksi awal hal-hal yang dilakukan adalah: a) peneliti mengumpulkan data-data berupa dokumentasi kondisional yang meliputi: Jumlah peserta didik, nama peserta didik dan nilai ekonomi peserta didik pada kelas $X \quad 7$ SMA Negeri 3 Palangkaraya tahun ajaran 2015/2016, b) peneliti melakukan observasi langsung dikelas dengan menanyakan guru mata pelajaran ekonomi kelas $X 7$ SMA Negeri 3 Palangkaraya, c) mengidentifikasi masalah, yaitu belum tercapainya indikator pembelajaran ekonomi, dan d) peneliti dan guru mata pelajaran ekonomi memutuskan rencana tindakan yang paling mungkin dilakukan untuk meningkatkan hasil belajat ekonomi melalui pembelajaran berbasis masalah (Problem Based Learning). Disini peneliti berkomfirmasi dengan guru mata pelajaran ekonomi menyusun jadwal pelaksanaan tindakan kelas.
Peneliti berperan sebagai instrument utama dalam penelitian yaitu peneliti merupakan pemberi tindakan yaitu sebagai praktisi membuat dan menyajikan bahan pembelajaran, motivator, dan fasilitator dalam kegiatan pembelajaran. Peranan peneliti selama pemberian tindakan adalah: 1) penyusunan rencana program pembelajaran (RPP), 2) pelaksanaan kegiatan pembelajaran, 3) pengamatan kegiatan belajar peserta didik, dan 4) Disamping itu dalam penelitian ini selain peneliti personil lain yang terlibat adalah peserta didik, guru mata pelajaran yang menjadi guru pamong serta pengawas.

Adapun rancangan dalam penelitian ini terdiri dari empat komponen yaitu perencanaan, tindakan, pengamatan, dan refleksi. Keempat komponen tersebut dipandang sebagai suatu siklus. Adapun siklus sebagai berikut:

Berdasarkan tahapan-tahapan seperti yang di gambarkan di atas, selanjutnya dapat di kembangkan lagi menjadi pelaksanaan penelitian tindakan kelas ini yang secara rinci yang dapat dijabarkan per siklus sebagai berikut:

\section{Perencanaan}

Pada tahap ini peneliti mengidentifikasi bagaimana menerapkan Strategi Pembelajaran Aktif Tipe Pembelajaran Berbasis Masalah ( Problem Based Learning/PBL ). Persiapan yang dilakukan untuk pelaksanaan penelitian tindakan kelas, yaitu: 1) peneliti melakukan analisis kurikulum untuk mengetahui kompetensi dasar yang akan disampaikan kepada peserta didik, 2) menyusun Rencana Pelaksanaan Pembelajaran (RPP), 3) mempersiapkan Strategi Pembelajaran Aktif tipe Pembelajaran Berbasis Masalah ( Problem Based Learning/PBL ) yang akan digunakan atau dipakai dalam pembelajaran, 4) 
membuat Lembar Kerja Peserta Didik (LKPD), dan 5) menyusun instrumen yang digunakan dalam pembelajaran.

\section{Pelaksanaan Tindakan}

1) Pendahuluan, guru mengkondisikan kelas Guru menjelaskan dan memperkenalkan metode pembelajaran Strategi Pembelajaran Aktif tipe Pembelajaran Berbasis Masalah (Problem Based Learning/PBL ) kepada peserta didik, guru menjelaskan tujuan pembelajaran yang ingin dicapai. 2) Kegiatan inti Guru menyampaikan materi yang akan disajikan serta memperlihatkan media yang akan dipergunakan dalam pembelajaran, guru melakukan prosses pembelajaran yang difokuskan kepada demonstrasi yang akan dilakukan oleh guru dan diikuti oleh peserta didik, peserta didik dipersilahkan untuk bertanya tentang materi pembelajaran yang baru saja disampaikan, setelah demontrasi guru meminta peserta didik untuk menjawab soal atau latihan yang ada pada lembar kerja. 3) Penutup, guru merangkum materi pelajaran, guru memberikan motivasi, evaluasi berupa pemecahan masalah terhadap materi yang tidak dipahami peserta didik dan memecahkan masalah tersebut, meminta peserta didik untuk berdo'a

Dari penelitian di atas yang menjadi subjek penelitian dalam penelitian ini adalah peserta didik kelas X-7 SMA Negeri 3 Palangka Raya sebanyak 37 pserta didik.

Untuk memperoleh data-data yang diperlukan dalam penelitian ini adalah menggunakan teknik: a. Dokumentasi, merupakan suatu teknik pengumpulan data dengan menghimpun dan menganalisis dokumen-dokumen, baik dokumen tertulis, gambar maupun elektronik. Pada penelitian ini dokumen yang dipergunakan adalah dokumen tertulis berupa data prestasi belajar atau hasil belajar peserta didik, b. Observasi atau pengamatan yang digunakan peneliti sebagai salah satu cara untuk mengumpulkan data melalui pengamatan langsung dilapangan yang hasilnya dicatat sebagai hasil pengamatan lapangan. Observasi dilakukan oleh 2 orang observer yaitu 1 orang mahasiswa dan 1 orang guru dengan mengisi lembar pengamatan yang tersedia, dan c) Tes hasil belajar, Tes dalam penelitian ini menggunakan pretest dan postest. Dimana pretest (kemampuan awal) untuk menilai kemampuan awal peserta didik mengenai materi pelajaran sebelum pembelajaran diberikan. Sedangkan pos test (tes hasil belajar Ekonomi) untuk menilai kemampuan peserta didik mengenai penguasaan materi pelajaran setelah pembelajaran dilaksanakan. Pos test dilakukan siklus I dan siklus II.Dikutip dari Alfy ( dalam Nana Syaodih Sukmadinata, 2013; 12) dalam contoh instrument penilaian: " Instrumen yang digunakan untuk menukur minat peserta didik melalui pengklasifikasian data dengan cara di beri bobot.Pemberian bobot terendahnya adalah 1 dan skor tertinggi adalah 4 .

Klasifikasi penilaian:

$$
\begin{array}{ll}
0,0-1,0 & =\text { Kurang } \\
1,1-2,0 & =\text { Cukup } \\
2,1-3,0 & =\text { Baik } \\
3,1-4,0 & =\text { Sangat baik }
\end{array}
$$

\section{Tes Hasil Belajar}

Tes dilakukan untuk mendapatkan data tentang hasil belajar peserta didik, sehingga diketahui apabila ada peningkatan hasil belajar atau belum. Adapun instrumen yang digunakan dalam tes adalah menggunakan 
LKPD/butir soal untuk mengukur hasil belajar peserta didik. Agar instrumen penelitian terarah dan mewakili materi pelajaran maska dibuatlah kisi-kisi soal tes hasil belajar seperti pada tabel di bawah ini:

Menganalisis data tingkat keberhasilan atau presentase keberhasilan peserta didik setelah proses belajar-mengajar setiap siklusnya dilakukan dengan cara memberikan evaluasi berupa soal tes pada setiap akhir tindakan. Berdasarkan ketepatan kemendiknas pada kurikulum KTSP peserta didik telah tuntas belajar bila telah mencapai skor 75 pada mata pelajaran Ekonomi dan ketuntasan proses pembelajaran mencapai $85 \%$. Untuk menganalisis ketercapaian proses pembelajaran setiap siklus dihitung dengan menggunakan statistik sederhana yaitu rata-rata nilai dirumuskan sebagai berikut:

$$
x=\frac{\sum x}{\sum N}
$$

Dengan:

$$
\begin{array}{ll}
X & =\text { Nilai rata-rata } \\
\sum X & =\text { Jumlah semua nilai peserta didik } \\
\Sigma N & =\text { Jumlah peserta didik }
\end{array}
$$

Menghitung persentase ketuntasan belajar peserta didik dengan rumus sebagai berikut:

$$
T B=\frac{\sum s \geq 65 \%}{n} \cdot 100 \%
$$

Keterangan:

$\sum \mathrm{s} \geq 65 \%=$ Jumlah peserta didik yang mendapatkan nilai lebih besar dari atau sama dengan 75 .

$\mathrm{N} \quad=$ Banyak peserta didik

$100 \%=$ Bilangan pengali tetap

TB = ketentutasan belajar

sumber: Suhardi R (Rinati,2013:34)

Tingkat ketercapaian (TK) pembelajaran dapat digunakan kriteria ketuntasan belajar, yaitu sebagai berikut:

$$
\begin{array}{ll}
80 \%-100 \% & =\text { Sangat Tercapai. } \\
70 \%-79 \% & =\text { Tercapai } \\
50 \%-69 \% & =\text { Cukup Tercapai. } \\
0 \%-49 \% & =\text { Sangat Kurang Tercapai. }
\end{array}
$$

Untuk melihat tingkat keberhasilan dari penelitian ini dengan indikator keberhasilan penelitian sebagai berikut:

1. Peningkatan aktivitas belajar peserta didik pada penelitian ini dapat ditentukan dari hasil observasi selama pembelajaran.

Apabila rata-rata skor:

$$
\begin{aligned}
& 0-1 \quad=\text { Kurang aktif } \\
& 1,1-2=\text { Cukup Aktif } \\
& 2,1-3=\text { Aktif } \\
& 3,1-4=\text { Sangat Aktif. }
\end{aligned}
$$

2. Penelitian ini dikatakan berhasil apabila hasil belajar peserta didik mencapai nilai ketuntasan individual $\geq 75$ dan secara klasikal terdapat $85 \%$ peserta didik yang memperoleh nilai $\geq 75$.

\section{HASIL dan PEMBAHASAN}

Berdasarkan tes uji kompetensi pada materi keuangan dan perbankan, dimana proses pembelajarannya dilaksanakan ternyata hasilnya kurang memuaskan, padahal peneliti sudah berupaya semaksimal mungkin menanamkan konsep pada materi tersebut. Hasil belajar yang diperoleh peserta didik pada Pre Test ini dari 17 peserta didik yang memperoleh nilai 75 ke atas hanya peserta didik, sedangkan yang memperoleh nilai di bawah 75 sebanyak 20 peserta didik.

Berdasarkan hasil pre-test di ata, maka dapat terlihat bahwa nilai hasil belajar peserta didik kelas X-7 SMAN 3 Palangkaraya dengan ketuntasan secara klasikal sebesar 45,95\% termasuk dalam kriteria sangat tidak tercapai. 
Jadi, dapat diketahui tingkat ketercapaian keberhasilan pembelajaran belum memenuhi syarat ketuntasan belajar secara klasikal.

Pada data siklus I yang terdiri dari: (a) data aktivitas guru dan aktivitas peserta didik, (b) data hasil belajar, dan (c) Indikator ketuntasan hasil belajar, (d) data refleksi siklus I. Data tersebut disajikan sebagai berikut: Perhitungan hasil observasi aktivitas guru dengan menggunakan rumus persentase. Dari dua orang observer di atas dapat diketahui jumlah skor aktivitas guru dari skor total 2,95. Perhitungan hasil observasi aktivitas peserta didik dengan menggunakan rumus persentase. Dari dua orang observer di atas dapat diketahui jumlah skor penilaian aktivitas peserta didik adalah 2,46. Data hasil belajar diperoleh dari tes yang dilakukan setelah selesai pelaksanaan kegiatan penelitian tindakan kelas (PTK) siklus I. Soal yang diberikan pada post-test ini sama dengan soal pre-test yang diberikan pada kegiatan sebelum tindakan, yaitu berjumlah 20 butir soal pilihan ganda. Berdasarkan hasil post test siklus I terlihat hasil belajar peserta didik kelas X7 5 SMAN 3 Palangkaraya dengan ketuntasan secara klasikal $64,86 \%$ termasuk dalam kriteria kurang tercapai. Sehingga hasil post-test siklus I belum memenuhi syarat ketuntasan belajar secara klasikal dan sebagian besar belum mencapai ketuntasan belajar yang ditetapkan untuk mata pelajaran Ekonomi yaitu 75.

Berdasarkan dari hasil diskusi peneliti dengan 2 observer, maka dapat disimpulkan bahwa peneliti masih banyaak melakukan kekurangan dalam hal: 1). penyampaian bahasa materi yang dilakukan peneliti masih kurang jelas, 2). mengadakan tanya jawab terhadap materi yang akan dibahas masih sangat kurang, 3). kurangnya peneliti dalam mengarahkan materi permasalahan sebagai contoh untuk pendalaman materi selanjutnya pemecahan masalah.

Berdasarkan uraian di atas yang perlu diperbaiki dalam siklus II yaitu: 1). peneliti harus memperjelas penggunaan bahasa dalam penyampaian materi pembelajaran, 2). memperbanyak tanya jawab kepada peserta didik dalam proses pembelajaran, 3). peneliti harus lebih jelas lagi mengarahkan diskusi yang dilakukan peserta didik agar dapat berjalan sesuai dengan yang diharapkan. Semua kekurangan dalam siklus I akan diperbaiki kembali pada siklus II dan peneliti akan melanjutkan ke siklus II.

Deskripsi data siklus II hampir sama dengan siklus I. Data siklus II terdiri dari data yang diperoleh dari: (a) data aktivitas guru dan peserta didik, (b) data hasil belajar, (c) Indikator ketuntasan hasil belajar, dan (d) data refleksi. Data tersebut disajikan sebagai berikut:

Data situasi belajar mengajar merupakan data tentang situasi belajar mengajar (aktivitas peserta didik) pada saat penelitian tindakan kelas berlangsung. Data tersebut diperoleh dari hasil observasi yang diisi oleh observer pada lembar observasi. Data tersebut di sajikan dalam tabel yaitu sebagai berikut:

Perhitungan hasil observasi aktivitas peserta didik dengan menggunakan rumus persentase. Dari dua orang observer di atas dapat diketahui jumlah skor penilaian aktivitas peserta didik adalah 3,3. Data hasil belajar 
diperoleh dari tes yang dilakukan setelah selesai pelaksanaan kegiatan penelitian tindakan kelas siklus II. Soal yang diberikan pada tes ini sama dengan soal yang diberikan pada siklus I yaitu berjumlah 20 soal pilihan ganda. Data tersebut disajikan pada tabel berikut ini:

Berdasarkan hasil post test siklus II terlihat hasil belajar peserta didik kelas $\mathrm{X} 7$ SMAN 3 Palangkaraya dengan ketuntasan secara klasikal 91,89 \% termasuk dalam kriteria Sangat Tercapai. Sehingga hasil post-test siklus II memenuhi syarat ketuntasan belajar secara klasikal dan sebagian besar peserta didik belum mencapai ketuntasan belajar yang ditetapkan untuk mata pelajaran Ekonomi yaitu 75. Sehingga penelitian ini tidak perlu dilanjutkan ke siklus III. Data refleksi dilakukan setelah kegiatan pembelajaran siklus II selesai. Saat melakukan refleksi ini, peneliti dan dua observer berdiskusi untuk membahas kegiatan belajar yang telah dilakukan berdasarkan hasil observasi. Pada siklus II ini peneliti tetap menggunakan Starategi Pembelajaran Aktif Tipe Pembelajaran Berbasis Masalah (Problem Based Learning) dalam proses pembelajaran Ekonomi. Dari hasil diskusi tersebut peneliti mendapatkan saran dari pengamat, dimana penggunaan Starategi Pembelajaran Aktif Tipe Pembelajaran Berbasis Masalah (Problem Based Learning) sebaiknya terus diterapkan dalam proses pembelajaran terutama pada pelajaran Ekonomi untuk meningkatkan pemahaman materi pelajaran pada peserta didik. Karena dengan adanya penggunaan Starategi Pembelajaran Aktif Tipe Pembelajaran Berbasis Masalah (Problem Based Learning ) mampu meningkatkan keaktifan peserta didik secara tidak langsung juga meningkatkan hasil belajar Ekonomi. Hal ini dapat dilihat pada hasil belajar peserta didik pada tabel 2 .

Berdasarkan hasil penelitian tindakan kelas yang dipaparkan di atas maka untuk mengetahui data yang diperoleh dari tiga tahapan penelitian yang telah dilakukan. Tahapan tersebut adalah: (1) penelitian pre-test, (2) penelitian tindakan kelas siklus I, dan (3) penelitian tindakan kelas siklus II.

Hasil penelitian pre-test dilakukan untuk mengetahui tingkat kemampuan pemahaman peserta didik sebelum melakukan tindakan pada mata pelajaran Ekonomi, yaitu pada materi Konsep Permintaan dan Penawaran Uang sebelum menggunakan Starategi Pembelajaran Aktif Tipe Pembelajaran Berbasis Masalah (Problem Based Learning) di kelas $\mathrm{X} 7$ SMAN 3 Palangkaraya, hal ini dapat dilihat dari hasil belajar peserta didik. Hasil observasi yang dilakukan pada tahap pre-test membuktikan bahwa hasil belajar peserta didik belum memuaskan, masih banyak peserta didik yang kurang aktif dalam proses pembelajaran dan pembelajaran yang digunakan model pembelajaran langsung. Sebagian besar peserta didik belum mencapai standar nilai yang sudah ditentukan, dan proses pembelajaran cenderung lebih berpusat pada guru. Hal ini dapat disimpulkan bahwa kurangnya keaktifan peserta didik baik bertanya maupun bersosialisasi terhadap sesama peserta didik, dan pada pembelajaran guru lah yang lebih sering aktif dari pada peserta didiknya. Hasil tes pre-test bertujuan untuk mengetahui sejauh mana kemampuan awal peserta didik sebelum penelitian tindakan kelas 
siklus I menggunakan Starategi Pembelajaran Aktif Tipe Pembelajaran Berbasis Masalah (Problem Based Learning) diterapkan. Hasil tes ini dijadikan sebagai dasar untuk mengetahui keberhasilan penelitian tindakan kelas selanjutnya. Tes yang dilakukan dalam pre-test terlihat bahwa hasil belajar peserta didik sangat kurang tercapai. Hal ini dikarenakan jumlah skor ketuntasan secara klasikal mencapai 45,95\% skor yang diperoleh peserta didik masih jauh dari indikator penelitian yakni 75. Berarti dapat disimpulkan bahwa tingkat pemahaman materi masih rendah, hal ini dapat dibuktikan dari hasil belajar dalam pre-test. Berdasarkan hasil observasi pada pre-test di atas, maka diperlukan suatu upaya untuk meningkatkan pemahaman peserta didik agar hasil belajar Ekonomi peserta didik pada materi Konsep Permintaan dan Penawaran Uang dengan Starategi Pembelajaran Aktif Tipe Pembelajaran Berbasis Masalah (Problem Based Learning) dapat ditingkatkan.

Hasil penelitian siklus I yang terdiri dari: (1) aktivitas guru dan peserta didik, (2) hasil belajar, dan (3) refleksi siklus I. Hasil penelitian tersebut disajikan sebagai berikut:

Data situasi belajar diperoleh dari observasi yang dilakukan pada kegiatan siklus I. Hasil observasi yang dilakukan pada siklus I tersebut sebagai berikut:

1) Aktifitas Guru, Penilaian pengamatan 10 bagian aktivitas guru dalam proses pembelajaran sebagai berikut: Berdasarkan penilaian jumlah skor aspek aktivitas guru selama proses pembelajaran secara klasikal mencapai 2,9 dengan demikian aspek aktivitas guru dapat dikategorikan cukup.
2) Aktivitas peserta didik, Penilaian pengamatan bagian aktivitas peserta didik sebagai berikut: Berdasarkan penilaian jumlah skor aspek aktivitas peserta didik selama proses pembelajaran secara klasikal mencapai 2,4 dengan demikian aspek dapat dikategorikan Aktif.

Dari hasil belajar siklus I belum mencapai indikator penelitian yaitu $64,86 \%$ hasil ini masih banyak yang belum mencapai kriteria ketuntasan mengajar (KKM) untuk pelajaran Ekonomi yaitu 75. Hasil belajar siklus I belum mencapai ketuntasan belajar secara klasikal. Jadi hasil penelitian pada siklus I ini tercapai secara individu belum secara klasikal atau keseluruhan.

Berdasarkan dari hasil diskusi peneliti dengan 2 observer, maka dapat disimpulkan bahwa peneliti masih banyak melakukan kekurangan dalam hal: 1). bahasa penyampaian materi yang dilakukan peneliti masih kurang jelas, 2). mengadakan tanya jawab terhadap materi yang akan dibahas masih sangat kurang, 3). kurangnya peneliti dalam mengarahkan materi permasalahan sebagai contoh untuk pendalaman materi selanjutnya pemecahan masalah.

Berdasarkan uraian di atas yang perlu diperbaiki dalam siklus II yaitu: 1) peneliti harus memperjelas penggunaan bahasa dalam penyampaian materi pembelajaran, 2) memperbanyak tanya jawab kepada peserta didik dalam proses pembelajaran, dan 3) peneliti harus lebih jelas lagi mengarahkan diskusi yang dilakukan peserta didik agar dapat berjalan sesuai dengan yang diharapkan. 
Penelitian siklus II dilakukan untuk meningkatkan hasil belajar, baik itu nilai, dan aktivitas peserta didik maupun sikap guru. Dimana terlihat pada siklus I kegiatan tersebut masih kurang maksimal, sehingga kemampuan pemahaman peserta didik pada mata pelajaran Ekonomi materi Konsep Permintaan dan Penawaran Uang tercapai, terlihat dari hasil evaluasi dan pengamatan oleh observer. Hasil penelitian tindakan kelas siklus II juga terdiri dari beberapa aspek antara lain: (1) aktivitas guru dan aktifitas peserta didik, (2) hasil belajar, dan (3) refleksi. Hasil penelitiannya sebagai berikut: Data situasi belajar diperoleh dari hasil observasi yang dilakukan pada siklus II. Hasil observasi pada siklus II sebagai berikut:

Aktivitas Guru, Penilaian pengamatan 10 bagian aktivitas guru dalam proses pembelajaran sebagai berikut: Berdasarkan penilaian jumlah skor aspek aktivitas guru selama proses pembelajaran secara klasikal mencapai 3,3 dengan demikian aspek aktivitas guru dapat dikategorikan Sangat Baik. Berdasarkan penilaian jumlah skor aspek aktivitas peserta didik secara klasikal mencapai 3,3 dengan demikian aspek aktivitas peserta didik dapat dikategorikan Sangat Aktif.

Berdasarkan data yang diperoleh, hasil belajar peserta didik telah mencapai indikator ketuntasan secara klasikal yaitu 91,89\%. Jadi hasil belajar Ekonomi peserta didik pada siklus II ini telah tercapai.

Berdasarkan hasil diskusi peneliti mendapatkan saran dari observer, dimana penggunaan Starategi Pembelajaran Aktif Tipe Pembelajaran Berbasis Masalah (Problem
Based Learning) sebaiknya terus diterapkan dalam proses pembelajaran terutama pada pelajaran Ekonomi untuk meningkatkan pemahaman belajar peserta didik.

Hasil penelitian memuat pengolahan data tentang: (1) nilai hasil belajar, (2) hasil pengamatan aktivitas peserta didik dalam kegiatan belajar mengajar.

Berdasarkan data di atas melalui perbaikan pembelajaran dengan menerapkan Starategi Pembelajaran Aktif Tipe Pembelajaran Berbasis Masalah ( Problem Based Learning) pada proses pembelajaran Ekonomi yang dilakukan oleh peneliti di kelas X7 SMAN 3 Palangkaraya tahun ajaran 2015/2016, menunjukan adanya peningkatan aktivitas peserta didik pada siklus I dan siklus II. Dari hipotesis tindakan yang berbunyi: "Ada peningkatan hasil belajar Ekonomi setelah menggunakan Starategi Pembelajaran Aktif Tipe Pembelajaran Berbasis Masalah (Problem Based Learning) pada peserta didik kelas X7 SMAN 3 Palangkaraya Tahun Pelajaran 2015/2016".

Meningkatnya nilai hasil belajar peserta didik kelas $\mathrm{X} 7$ SMAN 3 Palangkaraya pada mata pelajaran Ekonomi, dikarenakan meningkatnya pemahaman materi pada peserta didik. Hal ini dikarenakan Starategi Pembelajaran Aktif Tipe Pembelajaran Berbasis Masalah (Problem Based Learning) yang digunakan untuk mempermudah pemahaman peserta didik pada saat pembelajaran berlangsung.

Berdasarkan data di atas, maka dapat diketahui bahwa hasil belajar peserta didik dari pre-test sampai post test siklus II telah 
mengalami peningkatan, pada pre test persentase ketuntasan klasikalnya hanya mencapai $45,95 \%$ dengan kategori sangat kurang tercapai, siklus I persentase ketuntasan klasikalnya mencapai $64,86 \%$ dengan kategori kurang tercapai, siklus II ketuntasan klasikalnya lebih meningkat hingga $91,89 \%$ dengan kategori tercapai.
Berdasarkan hasil penelitian yang diperoleh maka dapat diketahui bahwa dengan menggunakan Starategi Pembelajaran Aktif Tipe Pembelajaran Berbasis Masalah (Problem Based Learning) dalam pembelajaran Ekonomi dapat meningkatkan aktivitas dan hasil belajar peserta didik.

Tabel 1. Sintaks Pelaksanaan Problem Based Learning.

\begin{tabular}{|c|c|}
\hline Tahap & Perilaku Guru \\
\hline $\begin{array}{l}\text { Tahap } 1 \\
\text { Orientasi peserta didik } \\
\text { kepada masalah }\end{array}$ & $\begin{array}{l}\text { Guru mmenjelaskan tujuan pembelajaran } \\
\text { menjelaskan logistic yang dibutuhkan, mengajukan } \\
\text { fenomena atau demonstrasi atau cerita untuk } \\
\text { memunculkan masalah, memotivasi siswa untuk } \\
\text { terlibat dalam pemecahan masalah yang dipilihnya. }\end{array}$ \\
\hline $\begin{array}{l}\text { Mengorganisasi peserta } \\
\text { didik untuk belajar. }\end{array}$ & $\begin{array}{l}\text { Guru membantu peserta didik untuk } \\
\text { mendefinisikan dan mengorganisasikan tugas- tugas } \\
\text { belajar yang terkait dengan permasalahan tersebut. }\end{array}$ \\
\hline $\begin{array}{l}\text { Tahap } 3 \\
\text { Membantu investigasi } \\
\text { mandiri dan kelompok. }\end{array}$ & $\begin{array}{l}\text { Guru mendorong peserta didik untuk } \\
\text { mendapatkan informasi yang tepat, melaksanakan } \\
\text { eksperimen, dan mencari penjelasan dan solusi. }\end{array}$ \\
\hline $\begin{array}{l}\text { Mengembangkan dan } \\
\text { Menyajikan hasil karya. }\end{array}$ & $\begin{array}{l}\text { Guru membantu peserta didik dalam } \\
\text { merencanakan dan menyiapkan karya yang sesuai } \\
\text { seperti laporan, video, dan model dan membantu } \\
\text { mereka untuk berbagi tugas dengan temannya. }\end{array}$ \\
\hline $\begin{array}{lr}\text { Tahap 5 } & \\
\text { Menganalisis } & \text { dan } \\
\text { mengevaluasi } & \text { proses } \\
\text { pemecahan masalah. } & \end{array}$ & $\begin{array}{l}\text { Guru membantu peserta didik untuk melakuakan } \\
\text { refleksi terhadap nvestigasinya dan proses-proses yang } \\
\text { mereka gunakan. }\end{array}$ \\
\hline
\end{tabular}

Tabel 2. Rekapitulasi Nilai Pengamatan Aktivitas Peserta Didik dalam Kegiatan Belajar Mengajar

\begin{tabular}{ccccc}
\hline No & Siklus & $\begin{array}{c}\text { Observer } \\
\text { I }\end{array}$ & $\begin{array}{c}\text { Observer } \\
\text { II }\end{array}$ & $\begin{array}{c}\text { Persentase Skor } \\
\text { Penilaian dari 2 observer }\end{array}$ \\
\hline 1. & Siklus I & 34 & 30 & 2,4 \\
\hline 2. & Siklus II & 43 & 42 & 3,3 \\
\hline
\end{tabular}




\section{KESIMPULAN}

Berdasarkan hasil penelitian yang telah dibahas maka dapat disimpulkan beberapa hal yaitu:

1. Aktifitas belajar peserta didik aktif pada saat proses pembelajaran Ekonomi dengan menggunakan Starategi Pembelajaran Aktif Tipe Pembelajaran Berbasis Masalah (Problem Based Learning) pada peserta didik kelas $\mathrm{X} 7$ SMAN 3 Palangka raya tahun pelajaran 2015/2016. Hal ini terlihat dari hasil persentasi skor rekapitulasi pengamatan dari dua observer, pada siklus I skor aktifitas peserta didik yaitu 2,4 dan pada siklus II skor aktifitas peserta didik yaitu 3,3.

2. Ada peningkatan hasil belajar Ekonomi setelah menggunakan Starategi Pembelajaran Aktif Tipe Pembelajaran Berbasis Masalah (Problem Based Learning) pada peserta didik kelas $\mathrm{X} 7$ SMAN 3 Palangkaraya tahun pelajaran 2015/2016. Hal ini telihat dari data hasil belajar peserta didik, pada siklus I hasil belajar peserta didik yaitu ketuntasan secara klasikalnya yaitu $64,86 \%$ dan pada siklus II meningkat menjadi $27,03 \%$ dan ketuntasan klasikalnya yaitu 91,89\%. Adapun standar ketuntasan minimum yang ditentukan sekolah untuk pelajaran Ekonomi yaitu 75 .

\section{DAFTAR PUSTAKA}

Amir Taufiq. M. (2009). Inovasi Pendidikan Melalui Problem Based Learning. Jakarta: KENCANA. Prenada Media Group.
Anurrahman, ( 2008). Belajar dan Pembelajaran. Bandung: Alfabeta.

E. Mulyasa. 2011. Kurikulum Yang Disempurnakan. Bandung: PT Remaja Rosdakarya.

Harawati, (2012). Penelitian Tindakan Kelas. Malang: Bayumadia Publishing. Husain Umar. 2007. Metode Penelitian Untuk Skripsi dan Tesis Bisnis. Jakarta: Raja Grafindo Persada.

Kunandar, (2010). Langkah Mudah Penelitian Tindakan Kelas Sebagai Pengembangan Profesi Guru. Jakarta: PT. Raja grafindo Persada.

Nana Syaodih Sukmadinata. 2005. Metode Penelitian Pendidikan. Bandung: Suharsimi PT.Remaja Rosdakarya

Sanjaya. 2011. Kurikulum dan Pembelajaran. Jakarta: Kencana Prenada Group. Sukmadinata Syaodih Nana. (2005). Metode Penelitian Pendidikan. Bandung: PT. Remaja Rosdakarya.

Sugiyono. (2010). Metode Penelitian Pendidikan. Bandung: PT Alfabeta.

Warsono dan Hariyanto. (2012). Pembelajaran aktif. Bandung: PT. Remaja Rosdakarya. 